\title{
CORTICOLOUS LICHENS AS INDICATORS OF DIFFERENT FOREST MANAGEMENT PRACTICES IN THE DOTALUGALA - KNUCKLES MOUNTAIN RANGE, SRI LANKA

\author{
G.S.K. Weerakoon ${ }^{1 *}$, S. Somaratne ${ }^{2}$, P.A. Wolseley ${ }^{3}$ and
} S.C. Wijeyaratne ${ }^{1}$
}

\author{
${ }^{1}$ Department of Botany, University of Sri Jayewardenepura, Sri Lanka \\ ${ }^{2}$ Department of Botany, Open University, Sri Lanka \\ ${ }^{3}$ Department of Botany, The Natural History Museum, London, UK \\ *Corresponding author: E-mail: gothamiew@sltnet.lk Tel-++ 94771869511
}

\begin{abstract}
Use of lichens as bioindicators in tropical zones has been hampered by lack of taxonomic and ecological knowledge. This study was conducted to assess the variation of lichen diversity in different forest management practices under different environmental conditions for their potential use as bioindicators of environmental alterations in Dotalugala, Knuckles mountain range. Data were analyzed to assess the relationship between lichen diversity and microclimatic conditions. In this study, 192 and 148 lichen species were recorded in natural and disturbed vegetation types respectively. The statistical analysis revealed a significant variation in lichen diversity between disturbed and undisturbed vegetations $(\mathrm{F}=6.213, \mathrm{df}=1 ; \mathrm{p} \leq 0.05)$. Lichen diversity in different vegetation types indicated a remarkable variation $(\mathrm{F}=3.21, \mathrm{df}=7 ; \mathrm{p} \leq 0.05)$. The regression tree analysis indicated, three important variables that determined the lichen diversity; type of vegetation, altitude and association with other Cryptogamic communities. The significant difference of corticolous lichen communities in the natural and disturbed vegetations may be due to the heterogeneity of microclimatic conditions. Specialist lichen communities found to be associated with pristine forests. Results of the present study suggest that lichens in the Knuckles mountain range could be considered as potential indicators in assessing ecological continuity within different vegetations and in the colonization of the regenerating habitats.
\end{abstract}

Key words: Lichen diversity, bioindicators, Knuckles mountain range, tropical forests, Sri Lanka

\section{INTRODUCTION}

Lichens have been widely considered as sensitive bioindicators of forest health and ecological continuity as well as atmospheric pollution in temperate climates (McCune, 2000, Brunialti \& Giordani, 2003, Wolsley et al., 2006). Their use in tropical zones has been hampered by lack of knowledge of the taxonomy of tropical species, their ecology and community structure (Wolseley \& Aguirre-Hudson, 2007). Hence, assessment and monitoring of lichen communities can only be undertaken once component taxa are known and their ecological and geographical distribution is understood (McCune, 2000). Also when phanerogams are scattered throughout large areas of forest and large sample area is essential to express the diversity of the forest, lichen communities in a small area reflect the range of habitats available, the species richness, and the amount of disturbance or degradation of the forest. Thus use of lichens may allow a rapid assessment of forest health and status in regions where other forms of environmental monitoring are expensive or impractical (Wolseley \& AguirreHudson, 2007). The identification of 'indicator' lichens can provide a basis for management recommendations and can also be used to assess climatic change and potential forest recovery in areas where deforestation has caused a change in local climate and phanerogamic communities (Wolseley \& Aguirre-Hudson, 2007).

Sri Lanka has a very rich floristic diversity and includes plants that belong to a variety of taxonomic groups. However, lower plant groups such as lichens have not received their due attention. As a result, limited research work carried out so far has confined to checklists and

Proceedings of the $15^{\text {th }}$ International Forestry and Environment Symposium, 26-27 November 2010.

Published by Department of Forestry and Environmental Science, University of Sri Jayewardenepura, Sri Lanka. 
taxonomic revisions. Thus knowledge with regards to the diversity and distribution of lichens is rather incomplete when compared to higher taxa.

The first collection of lichens of Sri Lanka was made by Thwaites during $1849-1880$. Several important literature have been compiled since then: Lichenese Ceylonenses (Nylander, 1900), Kandy Flora (Alston, 1938), Accounts of Anaptychia \& Parmeliaceae (Kurokawa, 1973, Kurokawa \& Mineta, 1973), A revision of the lichen family Thelotremataceae in Sri Lanka (Hale, 1980), checklist of 546 species together with synonymy in 14 fascicles by Brunnabauer (1986). Further, few other lichenological excursions and publications done by Moberg (1986 \& 1987), Awasthi (1991 \& 2007), Makhija \& Patwardhan (1992), Breuss \& Brunnbauer (1997), Vezda et al., (1997) and Orange et al., (2001) have brought the number of lichen species recorded up to 696. According to unpublished data and ongoing research findings, the lichen species could possibly outnumber the other faunal or floral records in Sri Lanka.

The Knuckles mountain range covers 2100 ha in the central mountain region of Sri Lanka, which is declared as a world heritage site at present. The aggregation of spectacular peaks is a unique feature, where general landscape of the area is extremely rugged with more than 35 peaks rising above $900 \mathrm{~m}$. The location and topography of the mountain region has resulted in a wide range of rainfall and temperature in different parts. Hence this is considered as a natural laboratory that encompasses all five climatic zones on island with five major forest formations (Bambaradeniya \& Ekanayake, 2003).

Major forest formations include montane, sub-montane, semi evergreen and extensive strips of riverine forests. Rock outcrop forests can be seen on rocky substratum where thin layer of soil is present. A mesmerizing world of stunted wind-sculpted trees exist in 'Pygmy' forests' above $1300 \mathrm{~m}$. Man- influenced semi - natural vegetation types present in the area include Wet and Dry Patana grasslands interspersed with Savana. Man influenced secondary vegetation types near forest edge areas include scrublands, home gardens, agricultural lands (tea, rice and chena) and plantations (Cardamom, Pinus, Eucalyptus and Acacia).

\subsection{RATIONALE}

Lichens have not been systematically inventoried or documented and the diversity and species distribution is not assessed in the Knuckles mountain range so far. The results of this pioneer lichenological study that is being conducted by the authors of this paper in the Knuckles mountain range are not yet conclusive, as systematic identification, inventorization and documentation of species recorded are being carried out at present.

This paper discusses the variations in lichen diversity in different forest management practices under different environmental conditions and their potential use as bioindicators of environmental alterations in different habitats in the Knuckles mountain range. These findings will be useful in recommending management practices to maintain and enhance Cryptogamic diversity in different vegetation types of this area.

\section{METHODOLOGY}

The sampling sites were chosen to include pristine forest of montane and sub-montane and six different disturbed vegetation types: tea, forest, Acacia \& Pinus plantations and secondary montane and sub-montane forests. Lichen species, their frequency and cover values were recorded together with environmental parameters (aspect, altitude, light intensity and canopy cover) in 20 sites of $100 \mathrm{~m}^{2}$ plots. Random coordinates were used to select ten trees within each plot and Diameter at Breast Height $(\mathrm{DBH} \geq 5 \mathrm{~cm})$, bark type and tree species were recorded. Sampling was done according to Wolsley et al., (2007). Collected lichens were identified using their morphology and chemistry (Arup et al., 1993). In few cases molecular 
studies were conducted (Prado et al., 2006, Campo et al., 2010). The bark pH of every sampled tree was measured using standard method (Smith et al., 2009).

The diversity index for each forest type was calculated using the Shannon-Wiener function (Maguran, 2007). The data collected on lichens were correlated with microhabitat conditions to assess the diversity and distribution in relation to a range of environmental gradients in disturbed and undisturbed habitats. Further, the data were analyzed to assess the relationship between lichen diversity and environmental conditions in different vegetation types using One-way Analysis Variance (ANOVA), Least Significant Difference (LSD) and Classification and Regression Tree (CART) analysis (Crawley, 2005, Maguran, 2007).

The regression tree (RT) modeling is a modern statistical technique suited for both exploratory and modeling ecological data that are often complex, unbalanced and contain missing values (Breiman et al., 1984; Clark \& Pregibon, 1992; Ripley, 1996, Baker, 1993; Rejwan et al., 1999). RT explains variation of a single response variable (categorical or numerical) by one or more explanatory variables (categorical and/or numeric). The tree is constructed by repeatedly splitting data where objective is partitioning the response variable into homogenous groups. The size of a tree equals the number of final groups that is characterized by either the distribution or mean value of the response variable, group size, and the values of the explanatory variables. All statistical analyses were carried out using the SPSS version 13 (SPSS /PC, 2009).

\section{RESULTS}

There were 192 lichen species recorded from the natural vegetations while 148 lichen species were present in the disturbed vegetation types in the Dotalugala, Knuckles mountain range. There was a considerable variation in the lichen diversity in different vegetation types and their nature of disturbance (Table 01). The lichen diversity between disturbed and undisturbed vegetations were significant $(\mathrm{F}=6.213, \mathrm{df}=1 ; \mathrm{p} \leq 0.05)$ and the highest lichen diversity was recorded for the pristine forest sites. Further, lichen diversity between different vegetation types indicated a considerable variation $(\mathrm{F}=3.21, \mathrm{df}=7 ; \mathrm{p} \leq 0.05)$.

When compared to all the other forest types in Dotalugala, the highest lichen diversity (1.91) was recorded in undisturbed sub-montane forest type. Despite the variation in tree species, DBH, bark characters and other microclimatic variables, the corticolous lichen communities recorded from montane and sub-montane forest plots demonstrate high degree of similarity. Characteristic indicator lichens included species of Myriotrema, Ocelllaria and Porina (Table 02) where pristine forest communities were characterized by a diverse association of lichens including many species of Thelotremoid Graphidaceae. One of these associations were distinguished by two lichen genera, Coccocarpia \& Leptogium, that dependent on high humidity and canopy cover and were present in the disturbed secondary forest sites as well.

The most dissimilar associations occurred in Acacia plantation sites, which support few nonforest and weedy lichen species (e.g., Pyxine spp., Heterodermia spp.). The lowest diversity was recorded for the forest and Pinus plantations (Table 01). Out of the four plantation sites, both tea and Acacia plantations have higher lichen diversity. The associations in tea plantations were distinguished by the presence of genera Herpothallon, Phyllopsora, Crocynia and a conspicuous contribution of sterile crusts. However, out of the six different disturbed habitats included in the study, the highest diversity was recorded in the disturbed secondary montane forests that have lichen communities similar to those present in pristine forest sites. 
Table 1: Shannon diversity indices for different vegetation types

\begin{tabular}{lll}
\hline Site & Vegetation type & Shannon diversity \\
\hline Undisturbed & Sub-montane forest & $\mathbf{1 . 9 1}$ \\
& Montane forest & 1.37 \\
Disturbed & Tea plantation & $\mathbf{0 . 7 0}$ \\
& Acacia plantation & 0.67 \\
& Pinus plantation & 0.52 \\
& Forest plantation & 0.58 \\
& Secondary montane forest & $\mathbf{1 . 2 0}$ \\
& Secondary sub-montane forest 0.74 \\
\hline
\end{tabular}

Table 2: Dominant lichen species present in different vegetation types

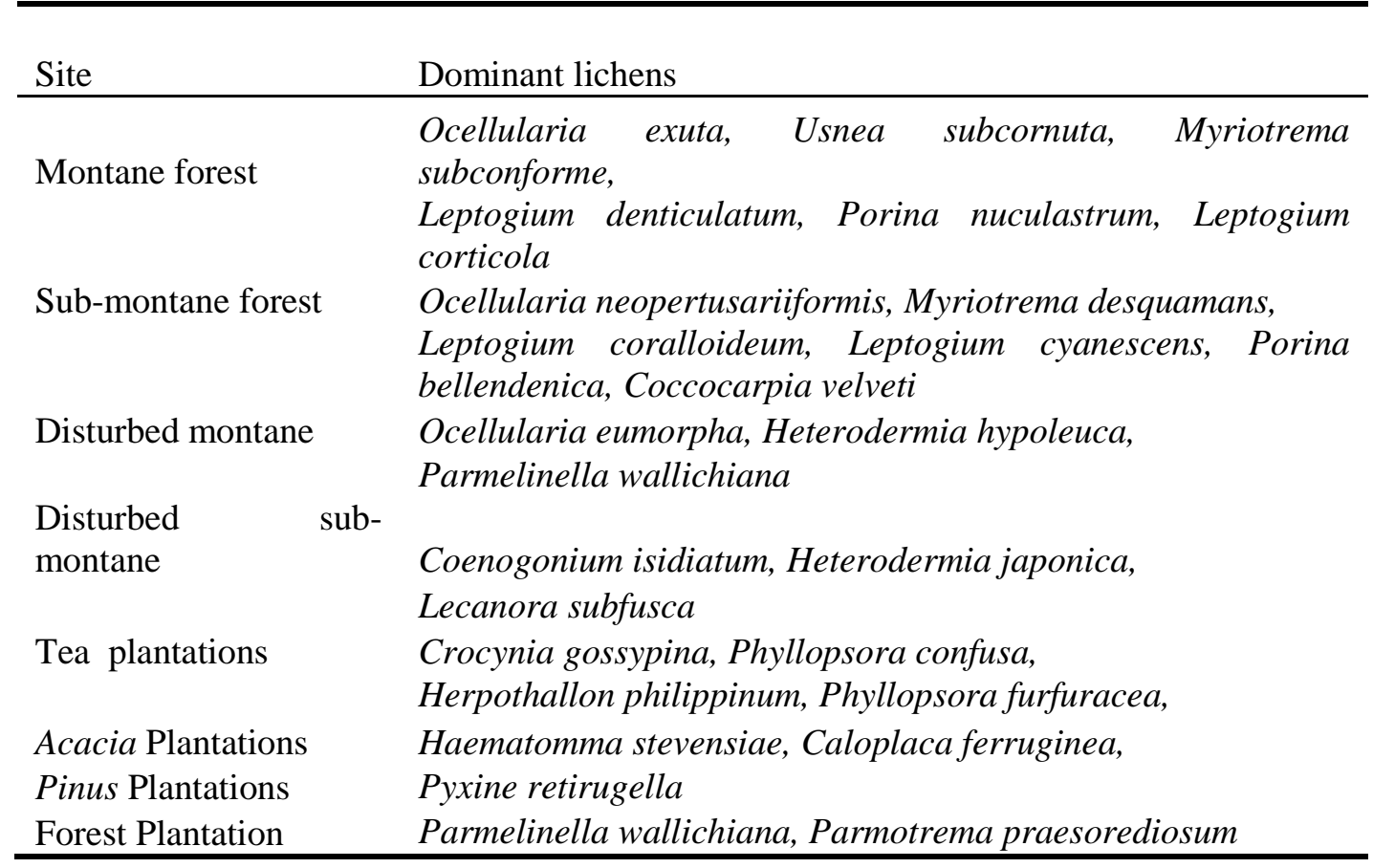

The results of the regression tree analysis (Fig. 01) indicated that values of diversity indices were split according to the importance of different variables measured or observed in different vegetation types. Based on the vegetation types of the study area, the entire dataset was split into three children nodes at the parental branch (first branch) of the regression tree. In this step, the pristine forest habitats (node 1 : Mean $=6.08$ ) and disturbed secondary montane forest (node 3: Mean=1.37) were well separated from the rest of the disturbed vegetation types (node 2: Mean= 6.49). The diversity indices of sub-montane and montane forest (node 1) were further divided into three children nodes based on the altitude at the second branch: child node 4 (Mean= 2.68) with altitude less than $1216 \mathrm{~m}$, child node 5 (Mean=0.76) with altitude ranging from $1216-1314 \mathrm{~m}$ and node 6 having highest altitudinal value $(\geq 1314 \mathrm{~m}$, Mean=1.27).

The most important variable that split child node 6 into two children nodes (node 7: Mean= 1.70 and node 8: Mean= 0.77) was the association of lichens with other Cryptogamic communities at the third branch. Hence, the RT analysis identified three important variables; 
type of vegetation, altitude and association with other Cryptogamic communities that determine the lichen diversity in different vegetation types of the study area.

\section{DISCUSSION}

The distribution of lichen species in Dotalugala area indicated a considerable spatial variation among different vegetation types in disturbed and undisturbed habitats. The study provides a good opportunity to compare and contrast lichen communities in pristine forests with communities of lichens in different vegetation to examine the effect of different management practices on micro community types, since all the sampled vegetation types belong to relatively homogenous climatic regime. This proved to be possible according to the studies conducted by Brunialti \& Giordani (2003) since lichen biodiversity values can be interpreted according to different scales of alteration from naturality within a homogenous climatic regime.

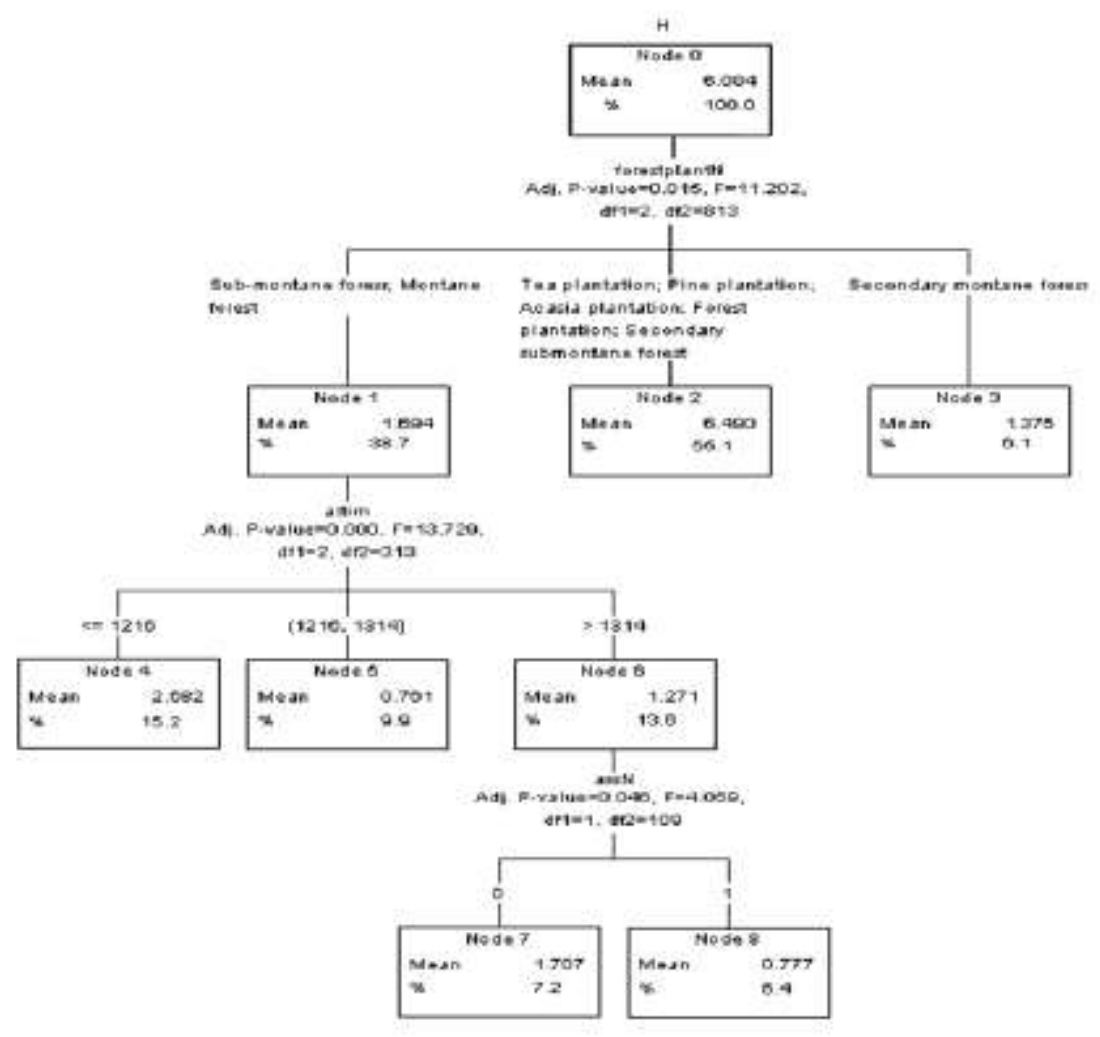

Figure 1: Decision tree resulted from the regression tree analysis of data collected from Dotalugala, Knuckles mountain range

Recent unprecedented increase of anthropogenic activities in the Knuckles area has exerted an unavoidable pressure on the health of the forest habitats. Thus, it is time to focus on the importance of lichen communities in the area that can be used as bioindicators to assess the magnitude of the disturbance or degradation of the forest habitats and to ensure the survival of biodiversity.

The results revealed that pristine forests contain the highest lichen diversity where certain species were seen spreading widely (e.g., Graphis spp., Leptogium spp. etc.). However, occurrence of other lichen species (e.g., Herpothallon, Phyllopsora \& Crocynia spp.) vary 
with the composition of forest such as those of the tea and Acacia plantations indicating their restriction to niches or adaptation to microhabitats, in particular to different vegetation types. The higher lichen diversity in tea plantation is probably be associated with relict forest species at low frequency (e.g., Crocynia species) and photophilous canopy species (e.g., species belongs to Graphidaceae) colonizing from canopy remnants indicating that shade trees provide a refuge for forest species of lichens (Holz \& Gradstein, 2005). Further, highest diversity that was recorded for the secondary montane forest out of the six disturbed habitats, indicate that lichens may rapidly colonize on the available substrata, where fragments of undisturbed forest or large trees remain (Wolseley et al., 2007). Lichen species were replaced by weedy lichen species (e.g., Pyxine spp., Heterodermia spp.) and low diversity in Pinus and Acacia plantations where logging was followed by conversion to agricultural uses and then even in aged-plantation of exotic tree species.

The findings of the present study agreed with the results and conclusions made out from the similar studies carried out in temperate and tropics (Wolseley \& Aguirre-Hudson, 2007, Saipunkaew et al., 2006, Brunialti \& Giordani, 2003, Wolseley, 1997).The studies carried in Thailand by Wolseley et al., (2007) showed that epiphytic Cryptogamic species of tree boles showed the highest diversity in pristine and selectively logged sites where canopy trees were maintained. Further, it was revealed that, in landscapes where tree cover is sparse or nonexistent, combined assessment of habitat diversity and indicator species can be used to assess changes associated with agricultural intensification by Wolseley et al., (2006). Therefore, results of present study also suggest that lichens in the Knuckles mountain range can be consider as potential indicators in assessing ecological continuity within different vegetations and in the colonization of the regenerating habitats.

The regression tree analysis provides the most important variables that contributed to the variation of lichen distribution in the disturbed and undisturbed forest habitats. Among these variables, type of vegetation, altitude and association of lichens with other Cryptogamic communities played a crucial role in determination of lichen distribution. However, the variation associated with lichen diversity and distribution of communities in disturbed vegetations was not well explained by the RT analysis. This could be due to the insufficiency of parameters that were included in the study. In contrast, the distribution of lichens of pristine forests that had already been observed to be dependent on associated Cryptogamic species at higher altitudes (>1300 m) during the field surveys were well explained by regression tree analysis.

\section{CONCLUSION}

The distribution of lichen species in Dotalugala area indicated a considerable spatial variation within different vegetation types of disturbed and undisturbed habitats. The results revealed that pristine forests contain highest lichen diversity where certain species occurred predominantly. The high lichen diversity in tea plantation indicates that loss of lichen diversity is not occurring at the selective logging stage, but following complete clearance of the forest and conversion to agriculture or plantation. Low diversity recorded from Pinus and Acacia plantations indicated that when the natural vegetation has been removed and replaced by exotic species, there is no source of lichen propagules or suitable substrata for colonization. Low diversity in forest plantations may have resulted since the recovery of specialist lichen species is slow due to poor dispersal (Wolseley et al., 2007) and absence of specialized habitats in this recently cultivated forest stands.

The potential use of lichens as bioindicators to access the degree of the disturbance and ecological continuity is highlighted from the present study. However, diversity and distribution of lichens in a particular area depends on a wide range of biotic and abiotic parameters and thus it is worthy to increase the number of parameters in the lichenological surveys to enhance the understanding of the ecological preference of lichens. 


\section{REFERENCES}

Alston, A.H.G., 1938. Kandy flora, Colombo, Sri Lanka. 1-50.

Arup, U., Ekman, S., Lindblom, L.,Mattsson,J., 1993. High performance thin layer chromatography (HPTLC), an improved technique for screening lichen substances. The Licheologist. 25, 61-71.

Awasthi, D.D., 1991. A key to the microlichens of India, Nepal and Sri Lanka. Bibliotheca Lichenologica. 40, 1- 337.

Awasthi, D.D., 2007. A compendium of the Macrolichens from India, Nepal and Sri Lanka, Bishen Singh Mahendra Pal Singh, India.1-580.

Baker, F. A., 1993. Classification and regression tree analysis for assessing hazards of pine mortality caused by Heterobasidion annosum. Plant Dis. 77, 136-139.

Bambaradeniya, C.N.B., Ekanayake, S.P., 2003. A guide to the biodiversity of Knuckles forest region, IUCN-The World Conservation Union, Sri Lanka. 4 -10.

Breiman, L., Freiman, J. H., Olshen, R. A., Stone, C. G., 1984. Classification and regression trees, Wadsworth International Group, California, USA. 45- 123.

Breuss,O., Brunnabauer,W., 1997. Flechten aus Sri Lanka. Annalen des Naturhistorisches Museums Wien. 99B, 727-735.

Brunialti, G., Giordani, P., 2003.Variability of lichen diversity in a climatically heterogeneous area. The Lichenologist. 35, 55-69.

Brunnabauer, W., 1986. Die Flechten von Sri Lanka in der Literatur. Botanische Abteilung Naturhistorisches Museums Wien. (in 14 teilen , als Kopien verteilt)

Campo, del., E.M., Hoyo, del., A., Casano, L.M., Martinez- Alberola, F., Barreno, E., 2010. A rapid and cost- efficient DMSO - based method for isolating DNA from cultured lichen photobionts. Taxon. 59, 588-591.

Clark, L. A., Pregibon, D.., 1992. Statistical models in S. Wadsworth, Pacific Grove, California, USA, 377-419.

Crawley, M.J., 2005. An Introduction using R. Second ed., John Wiley \& sons, Ltd, UK. 45-92.

Hale, M.E., 1980. A revision of the lichen family Thelotremataceae in Sri Lanka. Bulletin of the British Museum, Botany series. 8, 227-332.

Holz, I., Gradstein,S.R., 2005. Cryptogamic epiphytes in primary and recovering upper montane oak forests of Costa Rica- species richness, community composition and ecology. Plant Ecology. 178, 547560 .

Kurokawa, S., 1973. Supplementary notes on the genus Anaptychia. Journal of the Hattori Botanical Laboratory. 37, 563-607.

Kurokawa, S., Mineta, M., 1973. Enumeration of Parmeliae of Ceylon. Annual report of the Nato Marine Laboratory. 13, 71-76.

Magurran, A.E., 2007. Measuring Biological Diversity, Blackwell Science Ltd, USA. 17- 56.

Makhija, U, Patwardhan, P.G., 1992. Nomenclatural notes on some species of Trypethelium. Inernational Journal of Mycology and Lichenology.5, 237-251.

McCune, B., 2000. Lichen communities as Indicators of Forest Health. The Bryologist.103, 353-356. 
Moberg, R., 1986. Rolfidium, a new lichen genus from Sri Lanka. The Licheologist. 18, 305-307.

Moberg, R., 1987. Lichenes selecti exsiccate Upsalensis.Fasc.2 (Nos 26- 50).Thunbergia.5, 1-9.

Nylander, W., 1900. Lichenes Ceylonenses. Acta Societatis Scientiarum Fennicae.1, 26- 36.

Orange, A., Wolseley, P., Karunaratne,V., Bombuwala, K., 2001.Two lepraioid lichens new to Sri Lanka. Bibliotheca Lichenologica. 78, 327-333.

Prado,del., R., Schmitt, I.,, Kautz, S., Palice, Z., Lucking, R., Lumbsch, H.T., 2006.Molecular data place Trypetheliaceae in Dothideomycetes . Mycological Research.110, 511-520.

Rejwan, C., Collins, N. C. Brunner, L. J Shulter, J., M. S., Ridgway, 1999. Tree regression analysis on the nesting habitat of smallmouth bass. Ecology. 80, 341-348.

Ripley, D. D., 1996. Pattern recognition and neural networks, Cambridge University Press, Cambridge, UK. 34 -54.

Saipunkaew, W., Wolseley, P.A., Chimonides, P.J., Boonpragob, K., 2006. Epiphytic macrolichens as indicators of environmental alteration in northern Thailand [Online]. Available from: http://www.elsevier.com/locate/envpol [Accessed 11 May 2006].

Smith, C.W., Aptroot, A., Coppins, B.J., Fletcher, A., Gilbert, O.L., James, P.W., Wolseley, P.A., 2009.The Lichens of Great Britain and Ireland, British Lichen Society, UK. 12 -15.

Vezda, A., Brunnabauer, W., Breuss,O.,1997. Flechten aus Sri Lanka. Annalen des Naturhistorisches Museums Wien. 99B, 737-742.

Wolseley, P., 1997. Response of epiphytic lichens to fire in tropical forests of Thailand. Bibliotheca Lichenologica. 68, 165-176.

Wolseley, P., Ellis, L., Chimonides, J., 2007. Corticolous lichen and moss communities in lowland dipterocarp forests under differing management regimes. Bibliotheca Lichenologica. 95, 583-603.

Wolseley, P.A., Aguirre-Hudson.B., 2007. Lichens as Indicators of Environmental Changes in the Tropical forests of Thailand [Online]. Available from: http://www.jstor.org/locate/envpol [Accessed 23 Jan 2007].

Wolseley, P.A., Stofer, S., Stofer, R., Mitchell, Truscott, A., Vanbergen, A., Chimonides,J., Scheidegger,C., 2006.Variation of lichen communities with land use in Aberdeenshire, UK. The Licheologist. 38, 307-322. 